\title{
A review of the 1988 and 2002 phocine distemper virus epidemics in European harbour seals
}

\author{
Tero Härkönen ${ }^{1, *}$, Rune Dietz ${ }^{2}$, Peter Reijnders ${ }^{3}$, Jonas Teilmann ${ }^{2}$, Karin Harding ${ }^{4}$, \\ Ailsa Hall ${ }^{5}$, Sophie Brasseur ${ }^{3}$, Ursula Siebert ${ }^{6}$, Simon J. Goodman ${ }^{7}$, \\ Paul D. Jepson ${ }^{7}$, Thomas Dau Rasmussen ${ }^{2}$, Paul Thompson ${ }^{8}$ \\ ${ }^{1}$ Swedish Museum of Natural History, Box 50007, 10405 Stockholm, Sweden \\ ${ }^{2}$ National Environmental Research Institute, Box 358, 4000 Roskilde, Denmark \\ ${ }^{3}$ Alterra-Marine \& Coastal Zone Research, PO Box 167, 1790 AD Den Burg, The Netherlands \\ ${ }^{4}$ Department of Marine Ecology, Göteborg University, Box 461, 40530 Göteborg, Sweden \\ ${ }^{5}$ Sea Mammal Research Unit, Gatty Marine Laboratory, University of St. Andrews, St. Andrews, Fife KY16 8LB, UK \\ ${ }^{6}$ Research and Technology Center Westcoast, University of Kiel, Hafentörn, 25761 Büsum, Germany \\ ${ }^{7}$ Institute of Zoology, Zoological Society of London, Regent's Park, London NW1 4RY, UK \\ ${ }^{8}$ University of Aberdeen, School of Biological Sciences, Lighthouse Field Station, George Street, Cromarty IV11 8YJ, UK
}

\begin{abstract}
We present new and revised data for the phocine distemper virus (PDV) epidemics that resulted in the deaths of more than 23000 harbour seals Phoca vitulina in 1988 and 30000 in 2002. On both occasions the epidemics started at the Danish island of Anholt in central Kattegat, and subsequently spread to adjacent colonies in a stepwise fashion. However, this pattern was not maintained throughout the epidemics and new centres of infection appeared far from infected populations on some occasions: in 1988 early positive cases were observed in the Irish Sea, and in 2002 the epidemic appeared in the Dutch Wadden Sea, 6 wk after the initiation of the outbreak at Anholt Island. Since the harbour seal is a rather sedentary species, such 'jumps' in the spread among colonies suggest that another vector species could have been involved. We discussed the role of sympatric species as disease vectors, and suggested that grey seal populations could act as reservoirs for PDV if infection rates in sympatric species are lower than in harbour seals. Alternatively, grey seals could act as subclinical infected carriers of the virus between Arctic and North Sea seal populations. Mixed colonies of grey and harbour seal colonies are found at all locations where the jumps occurred. It seems likely that grey seals, which show long-distance movements, contributed to the spread among regions. The harbour seal populations along the Norwegian coast and in the Baltic escaped both epidemics, which could be due either to genetic differences among harbour seal populations or to immunity. Catastrophic events such as repeated epidemics should be accounted for in future models and management strategies of wildlife populations.
\end{abstract}

KEY WORDS: Epizootic $\cdot$ Harbour seal $\cdot$ Mass mortality $\cdot$ Phocine distemper virus Resale or republication not permitted without written consent of the publisher

\section{INTRODUCTION}

In recent decades there has been a global increase in reports of disease outbreaks in marine organisms (Harvell et al. 1999). Mass mortalities amongst plant, invertebrate, and vertebrate populations have led to dramatic changes in abundance and community structure, and it has been suggested that these events play an important role in shaping long-term population dynamics and thereby influence evolutionary processes (Harwood \& Hall 1990). Mass mortality events in marine mammals have attracted much concern. In some cases, investigations have confirmed that deaths resulted directly from anthropogenic effects such as fisheries by-catch (Kuiken et al. 1994). In others, such as in Galapagos fur seals and sea lions, 
natural reductions in food supply driven by El Niño conditions have led to high levels of mortality (Trillmich \& Dellinger 1991).

There is also increasing evidence for mortality resulting from infectious disease. In 1988, up to $60 \%$ of North Sea harbour seals Phoca vitulina died during an outbreak of a then newly discovered distemper virus identified by inclusion bodies (e.g. Dietz et al. 1989a, Bergman et al. 1990, Heide-Jørgensen et al. 1992). This virus was isolated and described as a morbillivirus, phocine distemper virus (PDV) (Osterhaus \& Vedder 1988). Subsequently, related dolphin and porpoise morbilliviruses were isolated from cetaceans (Barrett et al. 1993), and widespread screenings suggest that many populations of pinnipeds, cetaceans and sirenians in the North Atlantic had been exposed to these viruses prior to and after the 1988 PDV outbreak (Dietz et al. 1989b, Duignan et al. 1995a,b,c, 1997a,b, Van Bressem et al. 2001). Clinical signs of disease were not recorded in many of the populations in which morbillivirus antibodies were detected (Duignan et al. 1995b, Nielsen et al. 2000).

Epidemics amongst Baikal seals Phoca sibirica (Mamaev et al. 1995) and Caspian seals Phoca caspica (Kennedy et al. 2000) were caused by infection by canine distemper virus, presumably after contact with terrestrial carnivores. In the early 1990s, more than 1000 striped dolphins Stenella coeruleoalba died in the Mediterranean as a result of infection by the dolphin morbillivirus (Aguilar \& Raga 1993) that has since been shown to be present in a number of other species and regions (Van Bressem et al. 2001). However, over the same period, there has been increasing evidence that mass mortalities amongst marine mammals can also result from fatal poisoning from toxic algal blooms, with well reported cases amongst sirenians (O'Shea et al. 1991) and pinnipeds (Scholin et al. 2000). Fresh carcasses for autopsies are often unavailable in these situations, making it extremely difficult to determine the primary causes of death. As a result, both toxins and morbilliviruses have been implicated at different stages of investigations into the mass mortalities of northwest Atlantic bottlenose dolphins Tursiops truncatus (Lipscomb et al. 1994) and Mediterranean monk seals Monachus monachus. Indeed, in both these and other cases, it remains possible that high levels of mortality could have resulted from an interaction between morbillivirus infection and other external stressors such as toxic algal blooms and environmental contaminants (Ross 2002). The 1988 PDV outbreak amongst North Sea harbour seals became one of the best studied wildlife disease outbreaks. Despite this, there remains considerable uncertainty over the source of infection, the route(s) by which it spread so quickly, and the reasons underlying marked differences in mortality rate in different parts of the North Sea (Heide-Jørgensen \& Härkönen 1992).

In the summer of 2002, thousands of dead harbour seals were again found in the Kattegat and Skagerrak and along North Sea coasts (Harding et al. 2002). The cause of death was soon shown to be the same, or close to identical, morbillivirus (PDV) that had affected these same populations in 1988 (Jensen et al. 2002). This second outbreak of PDV therefore provided a possibility to compare the epidemiology of the disease on 2 separate occasions. In this review, we integrated data from a variety of sources and compared the dynamics of the 2 PDV outbreaks. In particular, we described the geographical pattern of dispersal, and reviewed possible sources and vectors for the PDV.

\section{DISTRIBUTION AND SPREAD OF THE EPIDEMICS}

\section{The 1988 epidemic}

The first report of the disease was 12 April 1988 at the island of Anholt in the central Danish Kattegat (Figs. 1 \& 2). The disease spread rapidly to other seal haulout sites, north and south of Anholt Island, then further to the western Kattegat and subsequently to the eastern Kattegat (Fig. 2). By the end of May 1988 the entire Kattegat harbour seal population was affected. From there it spread north and south along the Swedish west coast. By mid-June the disease reached the southwestern Baltic (Fig. 2). The population in Oslo Fjord was affected in early July, and within a few weeks it spread along the coasts of southwestern Norway up to about $65^{\circ} \mathrm{N}$. Meanwhile, during the 2nd wk of June the epidemic had also reached the Wadden Sea (Fig. 2). Surprisingly, it arrived first in the western part of the Dutch Wadden Sea, and then at seal colonies in the entire Wadden Sea almost simultaneously between 9 and 12 June (Fig. 2). The disease entered the Limfjord (Denmark) on 13 June and the Wash (southeast UK) on 21 July. Orkney, the northeast coast of Scotland, and the east coast of Northern Ireland were affected simultaneously in August. By September it finally spread throughout the rest of Scotland and the Shetland Islands (Fig. 2).

\section{The 2002 epidemic}

A different geographical and chronological pattern of dispersal was apparent in 2002 (Figs. 2 \& 3). Although it again started on Anholt, the first case was 


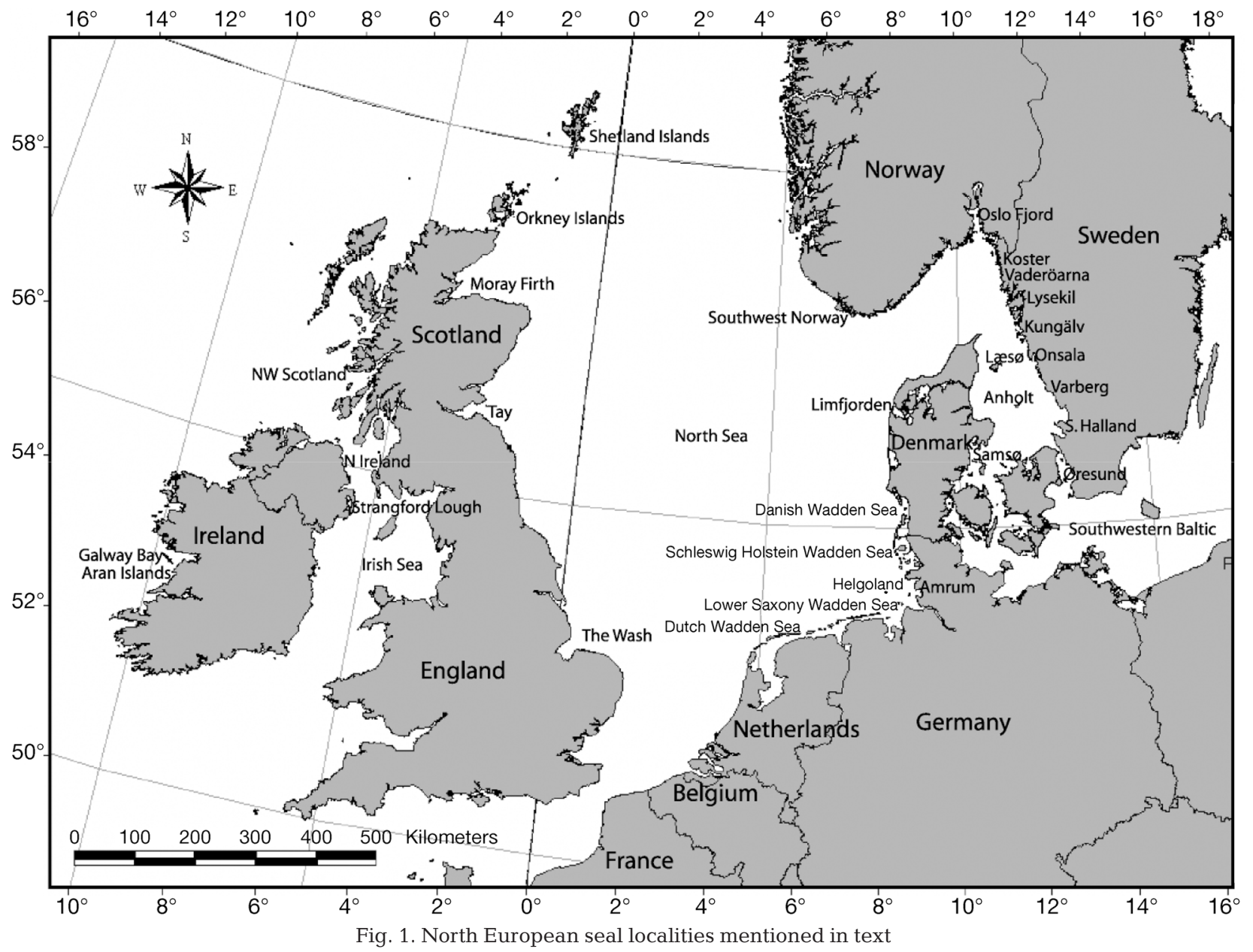

observed on 4 May, about 3 wk later than in 1988. It reached the Swedish Kattegat/Skagerrak area by 30 May, and then spread north to southern Norway in mid-June. Seals in the southwestern Baltic became infected around 17 July, one month later than in 1988 (Fig. 2). Again the disease suddenly jumped to the Wadden Sea, also this time it reached the Dutch Wadden Sea first. Here, the first PDV case was reported from the western part of the Dutch Wadden Sea on 16 June. This time it subsequently spread to Helgoland, and about 1 mo later (16 July) spread further to Lower Saxony. The disease was observed in Schleswig-Holstein on 11 August, and in the Danish part of the Wadden Sea on 26 August. By 11 August the first record of the epidemic was confirmed in the Wash in the UK, while the Limfjord was not affected until 18 September, more than 3 mo later than in 1988. Colonies in Scotland (at the Tay estuary and Moray Firth on the east coast) were first affected in September, with the first cases on the northwest coast of Scotland being reported in October (Fig. 2). The first case on the west coast of Ireland (the Aran Islands) was reported on 21 Sep- tember, and the first case in Northern Ireland (County Down) on 8 October.

\section{Comparison between the spread of PDV in 1988 and 2002}

The epidemics in 1988 and 2002 both started at Anholt (Fig. 1), and subsequently spread to other harbour seal colonies in a puzzling pattern (Fig. 2). In both 1988 and 2002, the colony in the Limfjord was affected at a late stage, in comparison to neighbouring colonies in the Kattegat, Skagerrak and Wadden Sea. In 2002 it appeared 3 mo later than in 1988. Scottish colonies were the last to be affected by the disease in both years (Fig. 2). In 1988 the disease 'jumped' from the Wash, or other areas, to Northern Ireland (Strangford Lough) and the southwest coast of Scotland. In 2002 the disease 'jumped' again to the Netherlands, but subsequently did not reach the Danish and German Wadden Sea as in 1988. In addition, the late infection of the southwestern Baltic in 2002, 1 mo later than in 1988, is intriguing. 

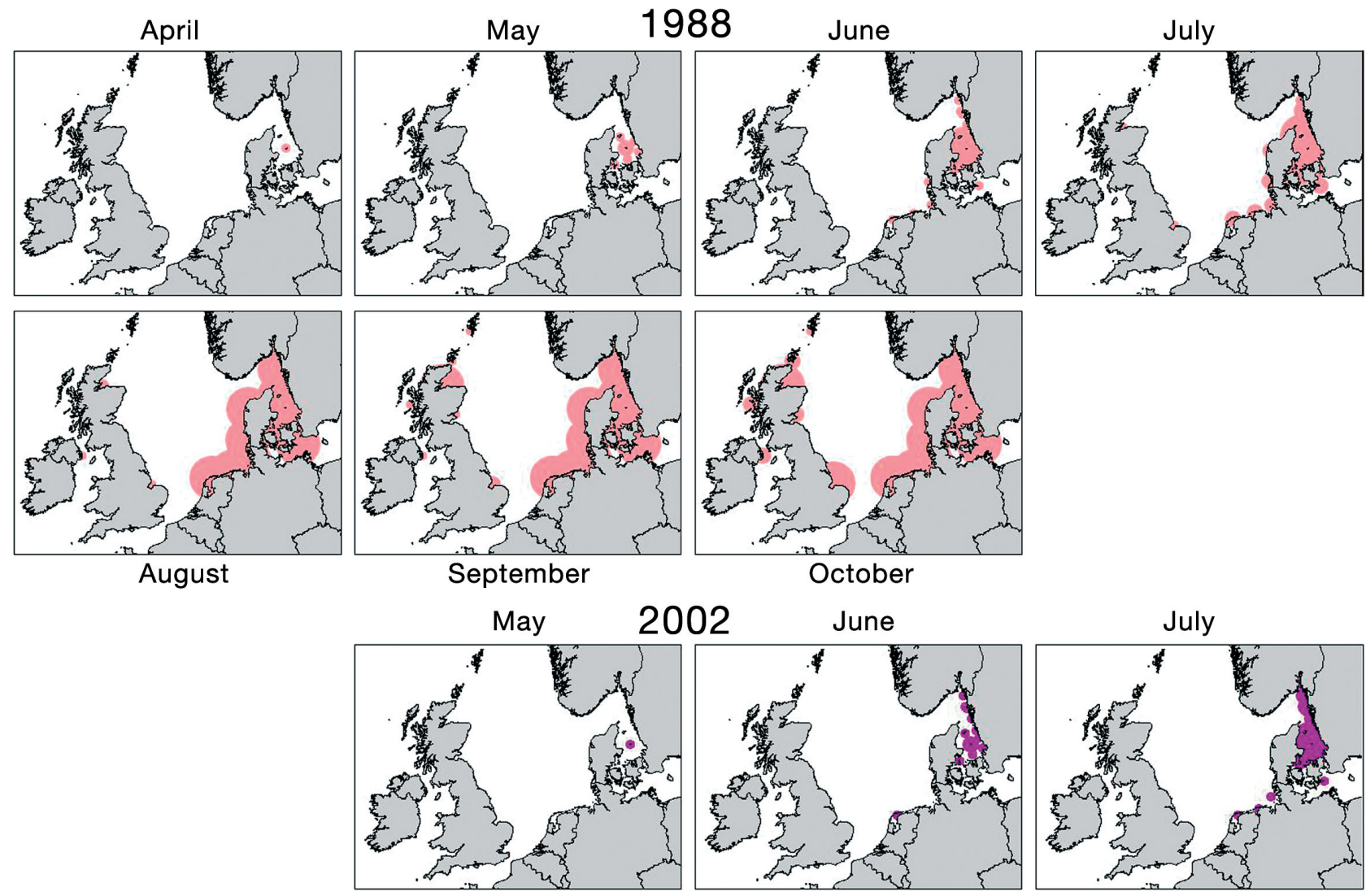

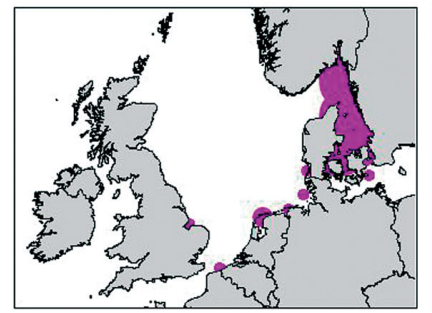

August

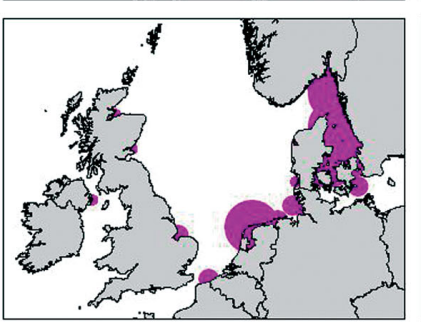

September

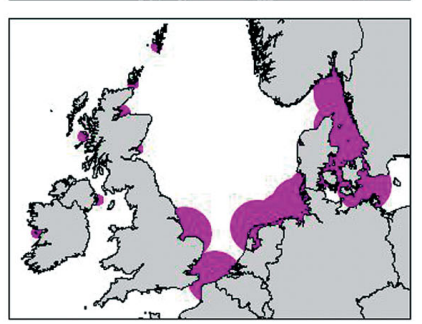

October

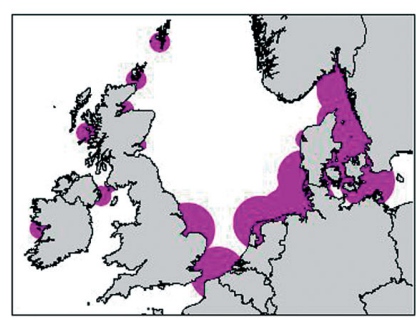

November

Fig. 2. Phoca vitulina. Progressive spread of PDV epidemics in northern Europe in 1988 and 2002

\section{Regional patterns in the duration of the epidemics}

Epidemic curves indicating the cumulative numbers found dead were constructed for each region (Fig. 3). There were likely differences in sampling and reporting effort early and late in the epidemic period. We therefore based our index of epidemic duration on the period between the first $5 \%$ and last $5 \%$ of dead seals reported for each region.

The epidemics in 1988 and 2002 both took about 9 mo to pass through all European harbour seal colonies, but differences in the site-specific durations were recorded. The cumulative death curves for Onsala and southwestern Baltic were similar in 1988 and 2002, when about $90 \%$ of all dead seals were reported within 6 to $8 \mathrm{wk}$. South Halland showed somewhat longer durations in both years: $90 \%$ of dead seals were observed within 10 to 11 wk. Unfortunately, data for the Danish Baltic, Danish Kattegat, Limfjord, and Samsø are only available for 2002. Cumulative curves in the Wadden Sea are similar to the Danish Kattegat and Samsø. Here, $90 \%$ of all dead seals were found within approximately $11 \mathrm{wk}$ compared to $13 \mathrm{wk}$ for the Danish SW Baltic. In the Limfjord the duration was much shorter at $7 \mathrm{wk}$. In some areas, such as the Wash in the UK and Galway Bay in Ireland, the epidemic event lasted for 10 to $11 \mathrm{wk}$. The longest recorded durations for both epidemics, at 14 to $19 \mathrm{wk}$, were noted in the Moray Firth and the Tay regions.

The main differences between the 1988 and 2002 epidemics were observed in the Wadden Sea, where the duration of epidemic in the entire area was considerably shorter at $11 \mathrm{wk}$ in 2002 compared to $16 \mathrm{wk}$ in 1988. This was also true at the sub-regional level: the patterns in 2002 in all 4 Wadden Sea areas differed 

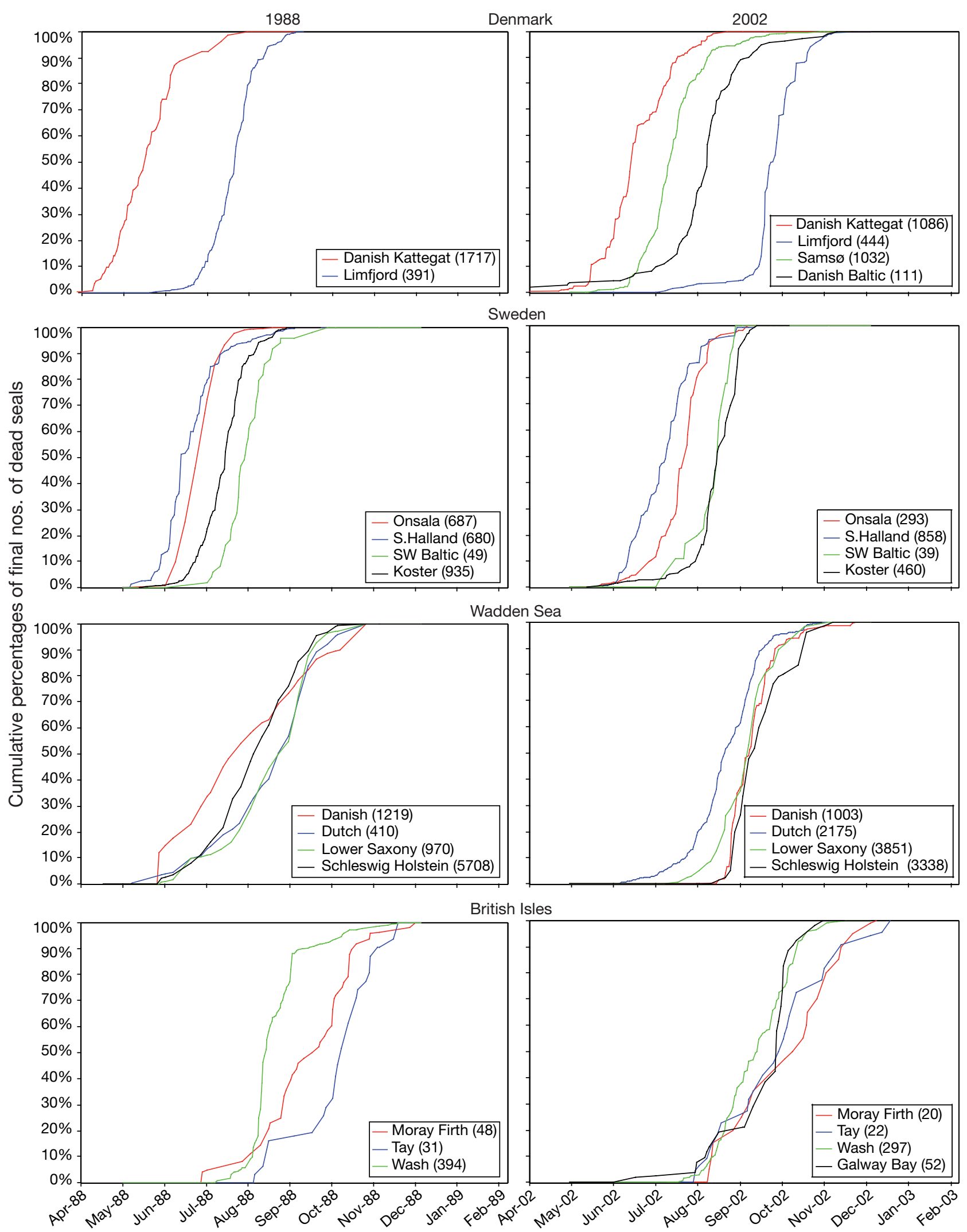

Fig. 3. Phoca vitulina. Epidemic curves for affected regions indicating cumulative numbers (\%) of seals found dead in northern Europe in 1988 and 2002. Note different slopes in the Wadden Sea for the 2 epidemic years. Numbers in legends indicate total cumulative numbers recorded dead in each area 
substantially compared to 1988. The duration in Denmark and Schleswig-Holstein combined was less than 8 wk in 2002, while in Lower Saxony $90 \%$ of dead seals were found within $10 \mathrm{wk}$. A similar pattern was observed in the Netherlands, where the duration was 11 to $12 \mathrm{wk}$. In all cases, these durations were more than 1 mo shorter than in the 1988 epidemic.

\section{Factors affecting differences in geographical spread}

The geographical dispersal of the disease showed some unexpected patterns both in the 1988 and 2002 epidemics. In 1988, this included the almost simultaneous finding of the first diseased seals on both the west coasts (Northern Ireland and southwest coast of Scotland) and the east coasts (the Wash) of the British Isles. In 2002, the initial discovery of the disease in the western Dutch Wadden Sea was similarly isolated (Fig. 2). This was particularly unexpected, given known movement patterns of harbour seals within the Wadden Sea (Harwood et al. 1989), and the considerable distance from the area in which the epidemic had started in the Kattegat. This suggests that 2 types of disease dispersal had occurred: (1) traditional contact-dispersal to adjacent colonies and (2) 'jumps'. It is theoretically possible that an infected harbour seal could swim during the incubation period from the Kattegat through the North Sea or the Kieler Canal straight to the western Dutch Wadden Sea. However, no existing data show such extensive migration in healthy harbour seals, and diseased seals would be even less likely to travel long distances in such a short period of time.

Alternatively, vectors other than harbour seals caused these unexpected 'jumps' between geographically separated colonies. Although PDV is not thought to be zoonotic, a human vector cannot be ruled out; however, no known movements of humans that had been in close contact with diseased seals fit the observed pattern of dispersal. Other species such as the grey seal Halichoerus grypus provide a more likely candidate. This species is known to carry PDV without being significantly affected (Barrett et al. 1995, Ries 1999). Indeed, viral RNA was found in blood samples collected from healthy, asymptomatic female grey seals breeding on the east (Isle of May) and northwest (North Rona) coasts of Scotland in late 2002 (Hammond et al. 2005), after the epidemic was over. Grey seals also travel long distances, e.g. from the Dutch Wadden Sea to Scotland (S. Brasseur \& P. Reijnders unpubl. data), from Scotland to the western Dutch Wadden Sea, and between Norway and Scotland (B. McConnell \& M. Fedak pers. comm.). One plausible scenario is that the outbreak started on Anholt, from where it was carried via the Kattegat/Skagerrak to other areas in the North Sea by grey seals. The existence of subclinical infected seals in this population may also help to partially explain the temporal and geographical spread of disease from the east to the west coast of Britain.

Intriguingly, grey seal haulouts are found both at the origin of the harbour seal epidemics (Anholt) and in most regions where the recorded jumps occurred: the Netherlands, Schleswig-Holstein, the Wash, the Irish Sea, and throughout Scotland.

\section{EPIDEMIC MORTALITY}

Mortality was estimated from systematic surveys before and after the 2 epidemics. Total mortality exceeded 23000 harbour seals in 1988 and 30000 in 2002 (T. Härkönen et al. unpubl. data), but mortality differed drastically among regions. In 1988 the highest mortalities ( $>50 \%$ ) were observed in the Kattegat, the Skagerrak, the Baltic, the Wadden Sea, and the Wash. These were all regions that were affected during the summer and early autumn (Heide-Jørgensen et al. 1992). In contrast, those areas affected in the late autumn suffered substantially lower losses. For example, only $13 \%$ of seals died in Moray Firth, and it is suggested that mortality rates in the Orkneys and the Shetlands could have been as low as $1 \%$ (Thompson \& Miller 1992).

The mortality patterns in the Wadden Sea differed between epidemics: approximately $57 \%$ died in 1988, and around $47 \%$ in 2002 . The death toll differed considerably more between epidemic years in other areas (Fig. 4). In 2002, the highest mortality was observed in the northern Skagerrak, where $66 \%$ died. This was greater than in 1988, whereas mortality in most other areas was lower in 2002 than in 1988. In 2002, low mortality in the Wash (22\%) and Scotland (1\%) may be attributed to late infection dates in these regions (Thompson et al. 2005, T. Härkönen et al. unpubl. data), since contact among seals decreases in late autumn (Härkönen et al. 1999). However, this feature cannot explain differences in mortality in the Danish Kattegat (Fig. 4) as the epidemics raged at similar times of year on both occasions. A comparable situation was seen in the Baltic, where $16 \%$ died in 2002 and $50 \%$ in 1988. It seems likely that factors other than season of infection influenced the reduced mortalities in 2002 in these regions. An alternative possibility is that differences in mortality between years resulted from greater acquired or innate immunity to PDV in those seal groups affected early in the 2002 epidemic. Apart from explaining the perceived lower mortality, immunity in part of the population would result in fewer morbillivirus infections, which may reflect what was observed in the Kattegat in 2002 (T. Härkönen et al. unpubl. data). 


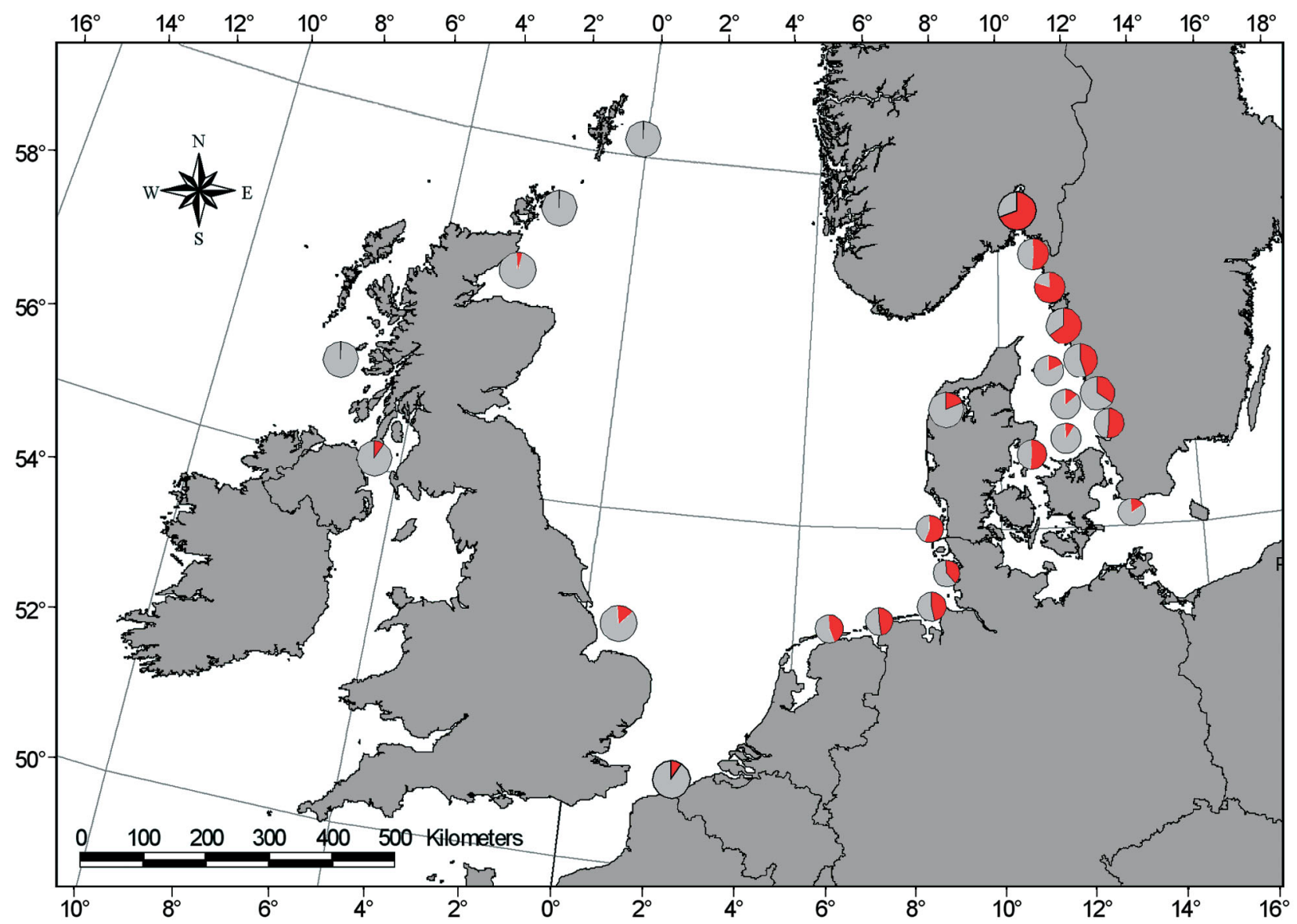

Fig. 4. Phoca vitulina. Regional differences in the proportion of seals that died in the 2002 PDV epidemic (shown in red)

\section{AGE- AND SEX-SPECIFIC MORTALITY}

In 1988, samples of teeth were used to determine the age of diseased seals that were collected in the Kattegat and the Skagerrak, permitting studies of age-and sexspecific mortality (Dietz et al. 1991). These data showed that mortality differed substantially among age classes. All pups of the year died in this area in 1988 (Härkönen et al. 2002), but sub-adults (ages 1 to 4 yr) suffered lower mortality compared to adults ( $>4 \mathrm{yr}$ ).

Significantly more males (55\%) died compared to females (45\%) (Härkönen \& Heide-Jørgensen 1990). Similar observations were made in the Wadden Sea (Reijnders et al. 1997). Furthermore, Härkönen \& Harding (2001) found that males from the Kattegat and Skagerrak were the first to be infected in each colony. It was also evident that the sex specific mortality had a seasonal component: the proportion of males among victims increased from $45 \%$ in May to $65 \%$ in August (Heide-Jørgensen \& Härkönen 1992). Close to $100 \%$ of adult males died in the Skagerrak, where the disease peaked in autumn.

In 2002, teeth from almost 4000 seals were collected from populations all along mainland Europe: the Baltic, the Kattegat, the Skagerrak, the Limfjord, and the Wadden Sea. Analyses of these samples are ongoing. Nevertheless, the basic pattern observed in 1988 appears to have been repeated in 2002, with more males than females dying and subadults suffering lower mortality compared to adults (T. Härkönen et al. unpubl. data)

\section{CLINICAL AND PATHOLOGICAL FINDINGS}

Clinical manifestation of disease caused by PDV infection included respiratory problems, fever, oculonasal discharge, conjunctivitis, ophthalmitis, keratitis, coughing, dyspnoea, diarrhoea, abortion, increased buoyancy, and an inability to dive (Bergman 1990, Kennedy 1990, Lawson \& Jepson 2004). Secondary infections by bacterial pathogens leading to death were often observed (Lawson \& Jepson 2004, Müller et al. 2004). The incubation time of an experimental morbillivirus infection in harbour seals was between 5 and $12 \mathrm{~d}$ (Harder et al. 1990).

The predominant pathological findings in seals were interstitial and purulent pneumonias with marked al- 
veolar and interstitial emphysema and generalised lymphodepletion (Kennedy 1990, Lawson \& Jepson 2004). Other less common findings were non-suppurative encephalitis and eosinophilic intracytoplasmic and intranuclear viral inclusion bodies in the brain, and predominantly eosinophilic intracytoplasmic inclusion bodies in various organs including lungs, liver, kidneys, pancreas, intestine, and brain (Kennedy 1990, Lawson \& Jepson 2004). Bordetella bronchiseptica was often isolated as a secondary bacterial infection (Jensen et al. 2002, Lawson \& Jepson 2004). Experimentally, changes in neutralizing serum antibody titres in seals were apparent from $16 \mathrm{~d}$ post infection (Harder et al. 1990).

In seals examined by necropsy, the minimum criterion used for determining a case of fatal phocine distemper was a combination of microscopic evidence of generalised lymphoid depletion and acute interstitial pneumonia, and molecular evidence of infection with PDV. The latter was usually confirmed by reverse transcriptase polymerase chain reaction or immunohistochemistry.

\section{SOURCES AND TRIGGERING MECHANISMS OF INFECTION}

\section{Morbilliviruses in marine mammals}

The virus family Paramyxoviridae contains 3 genera: Paramyxovirus, Morbillivirus and Pneumovirus. Morbillivirus spp. infections cause significant mortality in humans and animals. Measles is responsible for up to 2 million childhood deaths in humans annually in the developing world. Rinderpest and peste des petite ruminants cause severe epidemics in domestic and wild ruminants in areas of the world where they remain endemic (Barrett 1999). Canine distemper virus (CDV) causes fatal disease in many species of carnivores. Arctic seals may have been infected by CDV several hundred or thousands of years ago by terrestrial carnivores, after which the virus evolved into PDV (Barrett 1999). Hitherto unknown morbilliviruses with potentially important ecological consequences for marine mammals have been discovered over the past $15 \mathrm{yr}$; PDV in seals, porpoise morbillivirus (PMV), and dolphin morbillivirus (DMV) in dolphins, whales and porpoises. While PDV and CDV are believed to be the most closely related morbilliviruses, PMV and DMV constitute a separate branch in the phylogenetic tree and are more distant from the ancestral progenitor virus (McCollugh et al. 1991, Rima et al. 1992, Blixenkrone-Møller et al. 1994, Barrett et al. 1995, Barrett 1999).

Samples taken from harbour seals in 1988 from Ireland, Denmark, and the Netherlands indicated that PDV was genetically identical among affected regions (Visser et al. 1990, Barrett et al. 1992). A comparison of the PDV isolates from 1988 and 2002 showed the strains to be almost identical (Jensen et al. 2002). Serological tests for PDV- and CDV-neutralizing antibodies in various pinniped samples collected prior to the 1988 PDV outbreak revealed that morbillivirus-specific antibodies were common among pinnipeds in the Arctic regions (Duignan et al. 1997a). PDV- and CDV-specific antibodies were detected in archived harp seal Phoca groenlandica samples collected prior to the 1988 outbreak from Canadian and Greenlandic waters, the West Ice (East of Greenland), and the Barents Sea (Table 1). Other species of Atlantic pinnipeds had also been in contact with morbilliviruses both prior to and after 1988. Among these were ringed seals Phoca hisp-

Table 1. Prevalence of antibodies against PDV/CDV in serum samples of seals from the northern and southern hemispheres

\begin{tabular}{|c|c|c|c|c|c|c|}
\hline Species & $\begin{array}{c}\text { Year of } \\
\text { sampling }\end{array}$ & Area & $\begin{array}{c}\text { Tested } \\
\text { no. }\end{array}$ & $\begin{array}{c}\text { Positive } \\
\text { no. }\end{array}$ & $\begin{array}{c}\text { Positive } \\
\%\end{array}$ & Source \\
\hline Harbour seal & $1984-88$ & North Sea & 134 & 0 & 0 & Osterhaus et al. $(1988,1989)$ \\
\hline \multirow{14}{*}{ Phoca vitulina } & 1988 & West Atlantic & 6 & 3 & 50 & ICES (1989) \\
\hline & 1988 & England & 32 & 20 & 63 & Carter et al. (1992) \\
\hline & 1989 & England & 28 & 3 & 11 & Carter et al. (1992) \\
\hline & 1990 & England & 14 & 0 & 0 & Carter et al. (1992) \\
\hline & Before 1988 & Northern Baltic & 10 & 0 & 0 & Klingenborg (1990) \\
\hline & 1988-89 & Northern Baltic & 14 & 0 & 0 & Klingenborg (1990) \\
\hline & $1981-89$ & Southern Baltic & 9 & 1 & 11 & Klingenborg (1990) \\
\hline & 1989 & United Kingdom & 56 & 31 & 55 & Harwood et al. (1989) \\
\hline & $1984-88$ & Alaska & 4 & 0 & 0 & Osterhaus et al. (1988) \\
\hline & 1989 & East Canada & 11 & 4 & 36 & Carter et al. (1992) \\
\hline & 1992 & Long Island & 2 & 2 & 100 & Duignan et al. (1993) \\
\hline & $1980-94$ & Northeast American coast & 387 & 143 & 37 & Duignan et al. (1995a) \\
\hline & 1991-92 & Northeast American coast & 36 & 30 & 83 & Duignan et al. (1995a) \\
\hline & $1992-93$ & Northwest American coast & $?$ & $?$ & 0 & Duignan et al. (1995a) \\
\hline
\end{tabular}


Table 1 (continued)

\begin{tabular}{|c|c|c|c|c|c|c|}
\hline Species & $\begin{array}{l}\text { Year of } \\
\text { sampling }\end{array}$ & Area & $\begin{array}{c}\text { Tested } \\
\text { no. }\end{array}$ & $\begin{array}{l}\text { Positive } \\
\text { no. }\end{array}$ & $\begin{array}{c}\text { Positive } \\
\%\end{array}$ & Source \\
\hline \multirow{11}{*}{$\begin{array}{l}\text { Grey seals } \\
\text { Halichorus grypus }\end{array}$} & $1980-81$ & Canada & 9 & 3 & 33 & Henderson et al. (1992) \\
\hline & 1989 & East Canada & 24 & 15 & 63 & Carter et al. (1992) \\
\hline & $1985-87$ & United Kingdom & 90 & 0 & 0 & $\begin{array}{l}\text { Harwood et al. (1989), } \\
\text { Carter et al. (1992) }\end{array}$ \\
\hline & 1988 & England & 16 & 0 & 0 & Carter et al. (1992) \\
\hline & 1988 & Scotland & 12 & 0 & 0 & Klingenborg (1990) \\
\hline & 1988 & United Kingdom & 73 & 2 & 3 & Harwood et al. (1989) \\
\hline & 1989 & United Kingdom & 45 & 43 & 96 & Cornwell et al. (1992) \\
\hline & $1981-89$ & Baltic & 30 & 0 & 0 & Klingenborg (1990) \\
\hline & 1990 & Baltic & 1 & 1 & 100 & Klingenborg (1990) \\
\hline & 1991 & Baltic & 1 & 1 & 100 & H. Dietz pers. comm. \\
\hline & $1980-94$ & Northeast American coast & 296 & 216 & 73 & Duignan et al. (1995a) \\
\hline \multirow{10}{*}{$\begin{array}{l}\text { Harp seal } \\
\text { Phoca groenlandica }\end{array}$} & $1985-86$ & West Greenland & 40 & 12 & 30 & Dietz et al. (1989b) \\
\hline & 1987 & Barents Sea & 10 & 1 & 10 & Klingenborg (1990) \\
\hline & 1987 & West Ice & 46 & 3 & 7 & Markussen \& Have (1992) \\
\hline & 1987 & Barents Sea & 28 & 0 & 0 & Markussen \& Have (1992) \\
\hline & 1987 & West Ice & 37 & 36 & 97 & Markussen \& Have (1992) \\
\hline & 1989 & Barents Sea & 68 & 67 & 99 & Klingenborg (1990) \\
\hline & Before 1988 & Kattegat & 1 & 0 & 0 & Klingenborg (1990) \\
\hline & 1988 & North Sea & 1 & 1 & 100 & P. Have (unpubl. data) \\
\hline & $1971-80$ & Canada & 10 & 3 & 30 & Henderson et al. (1992) \\
\hline & $1988-93$ & Canada & 157 & 130 & 83 & Duignan et al. (1997a) \\
\hline \multirow{2}{*}{$\begin{array}{l}\text { Hooded seal } \\
\text { Cystophora cristata }\end{array}$} & $1983-84$ & Canada & 11 & 2 & 18 & Henderson et al. (1992) \\
\hline & $1989-94$ & Canada & 185 & 44 & 24 & Duignan et al. (1997a) \\
\hline \multirow{7}{*}{$\begin{array}{l}\text { Ringed seal } \\
\text { Phoca hispida }\end{array}$} & 1972 & Canada & 3 & 2 & 67 & Henderson et al. (1992) \\
\hline & $(1992)-94$ & Canada & 259 & 106 & 41 & Duignan et al. (1997a) \\
\hline & $1981-89$ & Baltic & 16 & 0 & 0 & Klingenborg (1990) \\
\hline & $1984-87$ & Greenland & 90 & 4 & 4 & Dietz et al. (1989b) \\
\hline & 1988 & NW Greenland & 10 & 0 & 0 & Bohm et al. (1989) \\
\hline & Before 1988 & Svalbard and Norway & 29 & 0 & 0 & Klingenborg (1990) \\
\hline & $1984-88$ & Alaska & 60 & 0 & 0 & Osterhaus et al. (1988) \\
\hline $\begin{array}{l}\text { Spotted seal } \\
\text { Phoca largha }\end{array}$ & $1984-88$ & Alaska & 8 & 0 & 0 & Osterhaus et al. (1988) \\
\hline $\begin{array}{l}\text { Bearded seal } \\
\text { Erignathus barbatus }\end{array}$ & $1984-88$ & Alaska & 5 & 0 & 0 & Osterhaus et al. (1988) \\
\hline $\begin{array}{l}\text { Stellar sea lion } \\
\text { Eumatopius jubatus }\end{array}$ & $1984-88$ & Alaska & 12 & 0 & 0 & Osterhaus et al. (1988) \\
\hline $\begin{array}{l}\text { Ribbon seal } \\
\text { Phoca fasciata }\end{array}$ & $1984-88$ & Alaska & 4 & & 0 & Osterhaus et al. (1988) \\
\hline Walrus & $1980-94$ & Canada & 3 & 3 & 100 & Duignan et al. (1994) \\
\hline Odobenus rosmarus & $1984-96$ & Canada & 131 & 65 & 50 & Nielsen et at. (2000) \\
\hline & $1984-88$ & Alaska & 158 & 0 & 0 & Osterhaus et al. (1988) \\
\hline $\begin{array}{l}\text { Weddel seal } \\
\text { Leptonychotes weddelli }\end{array}$ & $1984-89$ & Antarctic & 24 & 0 & 0 & $\begin{array}{l}\text { Osterhaus et al. (1988), } \\
\text { Bengston et al. (1991) }\end{array}$ \\
\hline $\begin{array}{l}\text { Crabeater seal } \\
\text { Lobodon carcinophagus }\end{array}$ & 1989 & Antarctic & 96 & 32 & 33 & Bengston et al. (1991) \\
\hline $\begin{array}{l}\text { Leopard seal } \\
\text { Hydrurga leptonyx }\end{array}$ & 1989 & Antarctic & 3 & 2 & 67 & Bengston et al. (1991) \\
\hline Baikal seal & 1988 & Lake Baikal & 83 & 45 & 54 & Grachev et al. (1989) \\
\hline Phoca sibirica & 1992 & Lake Baikal & 45 & 45 & 100 & Mamaev et al. (1995) \\
\hline $\begin{array}{l}\text { Caspian seal } \\
\text { Phoca caspica }\end{array}$ & 2000 & Caspian Sea & 16 & 12 & 75 & Kennedy et al. (2000) \\
\hline
\end{tabular}


ida in Canada and Greenland (Dietz et al. 1989b, Duignan et al. 1997a, Henderson et al. 1992), and harbour seals, grey seals, hooded seals Cystophora cristata, and walruses Odobenus rosmarus from the American and Canadian Atlantic coast (Henderson et al. 1992, Duignan et al. 1994, 1995a, 1997a, Nielsen et al. 2000) (Table 1). Except for a suggested PDV outbreak in harbour seals along the northeast coast of the USA in winter of 1991-1992 (Duignan et al. 1993, 1995a), no elevated mortality was reported in these species. In contrast, no PDV-specific antibodies were detected in ringed seals, spotted seals Phoca largha, ribbon seals Phoca fasciata, Steller sea lions Eumatopius jubatus, bearded seals Erignathus barbatus, and walruses from the northern Pacific (Osterhaus et al. 1988) (Table 1). However, CDV has been circulating in the Antarctic. CDV-specific antibodies were detected in crabeater seals Lobodon carcinophagus and leopard seals Hydrurga leptonyx seals, but not in Weddell seals Leptonychotes weddelli (Osterhaus et al. 1988, Bengtson et al. 1991).

\section{Linkage to terrestrial carnivores}

In 1987, 30000 seals died in Lake Baikal due to PDV2 (Grachev et al. 1989, Mamaev et al. 1995). It was concluded that PDV-2 was actually a strain of CDV, indicating that this event was unrelated to the north European outbreak in 1988 (Osterhaus et al. 1989, Visser et al. 1990, Barrett et al. 1992). In the spring of 1997 and 2000, mass deaths of Caspian seals occurred and the cause was diagnosed as a different CDV strain (Mamaev et al. 1995, Barrett 1999, Hall et al. 1999, Kennedy et al. 2000). The similarity between the Baikal seal virus and CDV suggested an epidemiological link to dogs in 'close contact with seals' (Grachev et al. 1989). However, a number of terrestrial carnivores such as foxes and mink could also be potential carriers of morbilliviruses. Studies into the transfer of virus between mink and seals have shown that crossspecies infection can occur (Blixenkrone-Møller et al. 1989). Mink were not part of the Danish fauna prior to 1930, and recent increases in escapes from Danish mink farms certainly increases the risk of disease transfer to native species. However, mink are not present on Anholt and it is unlikely that they acted as a primary intermediate host in the recent epidemics.

\section{The origin of the 1988 epidemic}

It has been suggested that the likely source of the 1988 epidemic was harp seals, which acted as the primary vector of the PDV (Dietz et al. 1989b, Hender- son et al. 1992, Markussen \& Have 1992) (Table 1). Support for this hypothesis was provided by records of mass migrations of harp seals into the southern Norwegian, Danish and Swedish waters in the winter of 1987-1988 (Dietz et al. 1989a, 1989b, Heide-Jørgensen et al. 1992, Markussen \& Have 1992). During this migration, 77000 harp seals died in nets along the coast of Norway (Haug et al. 1991). The likely reason for this exodus was the collapse of the capelin stock in the Barents Sea, which also had dramatic effects on cod Gadus morhua and seabird populations (Haug et al. 1991). Harp seals were not documented around Anholt, but were seen in the vicinity of harbour seal haul-out sites in the North Sea (Heide-Jørgensen et al. 1992, Reijnders \& Brasseur 2003).

\section{The origin of the 2002 epidemic}

Following the 1988 epidemic, there was no evidence that the PDV had been circulating among European harbour seals (Jensen et al. 2002, Thompson et al. 2002), and the 2002 outbreak most probably resulted from cross-species infection. In contrast, PDV has continued to circulate in the Arctic (Table 1). There are no records of harp seals moving into the North Sea in the years between the 1988 and 2002 outbreak. Nevertheless, it remains possible that harp seals, or some other arctic seals, introduced the disease to European waters. However, as the 1988 and the 2002 outbreaks both started at Anholt Island, the ecological characteristics of this site deserve further scrutiny in the search for possible vectors. One striking features of this site is that small numbers of grey seals (5 to 10) often haul out amongst large numbers of harbour seals (500 to 1000). Here, harbour and grey seals haul out close together, and are not separated into groups as seen at other localities where numbers of grey seal are larger. Consequently, the grey seals at Anholt are potential candidates for transferring PDV to harbour seals. Intriguing in this respect is the fact that in the Dutch Wadden Sea, grey seals have hauled out between and close to harbour seal colonies since the early 1980s (Reijnders et al. 1995).

\section{PDV in grey seals}

Only about $1 \%$ of the dead seals found in 1988 were grey seals (Heide-Jørgensen et al. 1992), which indicated that grey seals are less sensitive than harbour seals to PDV infection as a large fraction had antibodies against PDV indicating exposure to the disease (Ries 1999). The possibility that PDV continued to circulate among grey seals after 1988 is supported by 
serological (ELISA) tests of PDV exposure taken in 1992 from grey seals at the Farne Islands, UK, where all 75 examined grey seals had positive PDV-specific titres. This was also true for juveniles born after the epidemic (Barrett et al. 1995). In comparison, in 1991 (3 yr after the first outbreak), only 40 to $60 \%$ of adult harbour seals and no juveniles from the Moray Firth were seropositive (Thompson et al. 2002). In the UK, a large proportion of the younger harbour seals seemed to have escaped infection as they appeared susceptible in the seroconversion tests 1 and $2 \mathrm{yr}$ after the epidemic (Carter et al. 1990, Cornwell et al. 1992, Ries 1999). However, maternal antibodies were present in samples from pups caught in the UK and Norway in 1990, 2 yr after the epidemic (Cornwell et al. 1992).

A recent study in the UK provided more evidence that grey seals might be important sources of infection. Hammond et al. (2005) found that approximately $5 \%$ of breeding females and $8 \%$ of their pups sampled from the Isle of May in the Firth of Forth, on the east coast of Scotland, tested positive for PDV in their white blood cells. On North Rona off the northwest coast of Scotland, $18 \%$ of females and $5 \%$ of their pups tested positive. All positive seals were asymptomatic, and pups that tested positive were aged 9 to $14 \mathrm{~d}$. However, only 1 had a viraemic mother so it is unlikely that the PDV was transferred maternally. These results illustrate that grey seals come into contact with infectious seals and can become infected themselves without displaying acute effects.

It is uncertain to what extent grey seals in the Baltic carry PDV. However, an adult male grey seal, tagged as a pup in Finland and trapped in a fyke net in southeastern Denmark 1991, was tested seropositive with antibodies against PDV (Table 1). Active infection is indicated to have occurred in 1990, when more than half of 30 dead grey seal pups examined in Estonia showed lesions (such as inclusion bodies in lung tissue) indicative of phocine distemper (B. Westerling pers. comm.). All other seals sampled in the Baltic and the Wadden Sea proved negative for PDV in serological and immunocytochemical tests (Table 1).

Due to intensive hunting and a bounty system on seals, the breeding population of grey seals in the Wadden Sea disappeared at the end of the middleages (Reijnders et al. 1995). In the Kattegat they disappeared before 1900, and the present low numbers originate from both the northeast Atlantic and the Baltic (Søndergaard et al. 1976, Härkönen et al. 2006). Grey seals equipped with satellite transmitters showed highly migratory behaviours (Dietz et al. 2003, S. Brasseur \& P. Reijnders unpubl. data), and it is therefore suggested that grey seals from Anholt may be in contact with both the Baltic and the northeast Atlantic populations during the breeding seasons.

\section{Factors required for maintaining PDV infection in populations}

Investigations following the 1988 PDV epidemic suggested that at least 300000 individuals are required to maintain morbilliviruses in circulation (Swinton et al. 1998). These estimates were based on the assumption of a constant basic reproductive rate of the infection $\left(R_{0}\right)$. However, absolute population size may not be so important once it is over a certain threshold level. Morbilliviruses are known to be highly virulent and the rate of transmission between infected and susceptible animals will determine how fast an epidemic will sweep through a population. Within smaller (panmictic) units, the $R_{0}$ was estimated at 3.18 (i.e. each infected seal transferred the disease to 3.18 seals), but the regional structure of European harbour seal populations reduced overall $R_{0}$ to 2.26 in 1988 and 2.35 in 2002 (T. Härkönen et al. unpubl. data).

The basic infection rate is a function of the duration of an epidemic (DOE) $\left(R_{0} \approx b[\log \mathrm{DOE}]^{-1}\right.$, where DOE is defined as the time between when the first $5 \%$ and the last $5 \%$ had died) (T. Härkönen et al. unpubl. data). An epidemic would therefore persist for more than $1 \mathrm{yr}$ only if the mean basic infection rate was below 2.15 (Fig. 5). Since information on the dynamics of PDV and related viruses in other seal populations is scarce, one must be cautious when speculating about minimum population sizes for other disease vectors. Nevertheless, the persisting occurrence of PDV/CDV in, for example, Arctic and Antarctic seal populations indicates that mechanisms may exist that lower the overall infection rate of the disease far below that of a panmictic unit of a harbour seal population. It is thus possible that morbilliviruses can circulate in smaller host populations than was previously believed. Baltic grey and/or ringed seals cannot be ruled out as potential sources of infection, despite the fact that the combined population size may be less than 30000 seals.

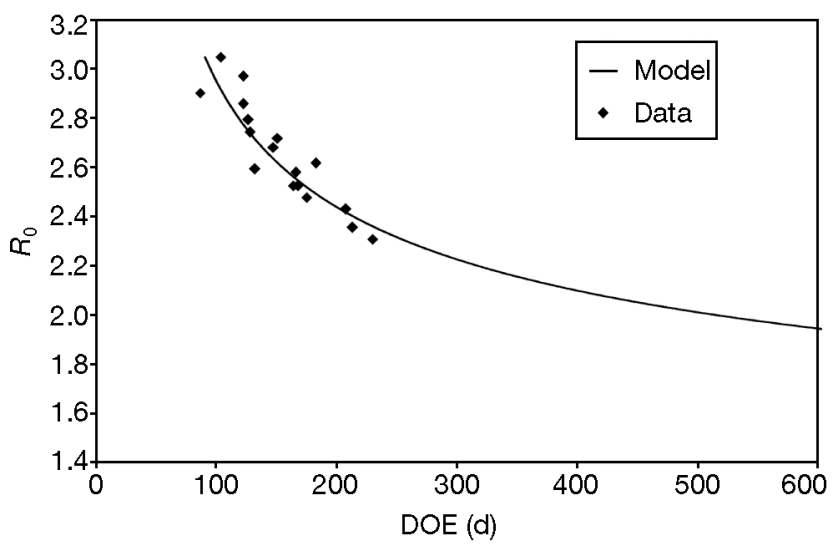

Fig. 5. Phoca vitulina. Relationship between reproductive rate of infection $\left(R_{0}\right)$ and duration of epidemic (DOE), measured as the time when the central $90 \%$ of seals died in each region 


\section{Potential genetic contributions to PDV susceptibility}

In recent years, there has been increasing evidence that host genetic variation plays an important role in determining susceptibility to infectious disease (Samson et al. 1996, Goodman 1998, Paterson et al. 1998, Acevedo-Whitehouse et al. 2003, Galvani \& Slatkin 2004). Such variation may be in loci directly related to immune function, such as Major Histocompatibility (MHC) Class I or Class II loci (Paterson et al. 1998), genes involved in infection pathways (Samson et al. 1996), or inbreeding effects. In the latter case, inbred individuals have shown greater susceptibility to disease than more outbred individuals (Acevedo-Whitehouse et al. 2003). One of the outstanding questions related to the 1988 and 2002 PDV epidemics is whether genetic variability influenced the different levels of mortality observed amongst harbour seals. Several lines of evidence suggest a potential genetic contribution to PDV susceptibility. There is large interspecific variation in mortality: PDV is endemic in Arctic species, but does not appear to cause significant mortality. Experimental evidence also demonstrates that grey seals mount a stronger neutralising immune response to PDV than do harbour seals (Duignan et al. 1997b). This suggests that there are species level differences in immune responses to PDV infections. The population level differences in mortality among European harbour seals suggest similar variation may exist within this species. Serological analyses after 1988 showed that most individuals from low mortality populations had been exposed to the virus, and that the same strain of virus was found in each population. Consequently, non-exposure or viral attenuation during the spread of the epidemic did not seem to account for this difference. Additionally, there are historical accounts of mass seal deaths, where animals were reported to have clinical signs consistent with PDV (Harwood \& Hall 1990). These accounts come from populations such as Orkney and Shetland that had low mortality in 1988 and 2002, suggesting that past exposure to PDV may have resulted in the selection of more resistant genotypes. Modelling studies show that such resistant genotypes can increase rapidly in frequency when subject to selection from recurrent epidemics (Galvani \& Slatkin 2004). Previous genetic studies of harbour seals showed that the European population is highly structured (Stanley et al. 1996, Goodman 1998), which would allow for differential distribution of loci that contribute to PDV resistance (Goodman 1995).

In contrast, there is no evidence that susceptibility to PDV is related to genetic impoverishment or lack of variation at MHC loci. Some of the most severely affected populations had high levels of genetic variation (Goodman 1998), and harbour seals have levels of vari- ation at MHC Class I loci comparable to other carnivores (Goodman 1995). Further work that builds upon recent advances in mammalian genomics is now required to resolve these outstanding questions of genetic variation and PDV susceptibility in harbour seals. The wealth of material and supporting data available from the 2 epidemics now make harbour seals an excellent system for further investigation of the role that genetic variation can play in determining susceptibility to infectious disease in natural populations.

\section{The role of environmental contaminants}

Amongst factors that influence variations in mortality, particularly in determining individual susceptibility, are those from an environmental origin (Jepson et al. 2005). The influence of organochlorine (OC) contamination on immune function was considered an implicating factor in the 1988 epidemic, but a causal relation could not be established (Hall et al. 1992a,b, Reijnders \& Aguilar 2002). It has also been hypothesised that the 1988 epidemic may have selected against those seals in the Wadden Sea population that carried the highest levels of OCs, notably PCBs and DDE (Reijnders et al. 1997, Reijnders \& Aguilar 2002). The abrupt improvement in population growth rate, in combination with reduced levels of OCs in seal blubber tissue after 1988, was the basis for this conclusion. Initially, this sudden improvement in population parameters could be due to a perturbed demography, where the surviving population was dominated by young adult females (Heide-Jørgensen \& Härkönen 1992). However, the population continued to grow at a rate that was close to the maximum expected for a harbour seal population with a stable age structure. This indicated that the overall fitness of the population had considerably improved compared to the pre1988 epidemic period (Reijnders et al. 1997, Härkönen et al. 2002). Preliminary toxicological analyses for PCBs and DDE have shown that levels in blubber of adult seals collected in 2002 from the heavily polluted part of the western Dutch Wadden Sea have decreased by 50 to $65 \%$ compared to 1988 (Aguilar et al. 2002, Reijnders \& Simmonds 2003). This further suggests that contamination with immunosuppressive OC compounds did not play a critical role in the seal epidemic in the Wadden Sea in 2002. Given the overall decreasing trend of PCBs and DDE in marine mammals in the northeastern Atlantic (Aguilar et al. 2002, Reijnders \& Simmonds 2003), it is likely that this conclusion also holds for other areas.

Nevertheless, more novel compounds of concern such as organotins and brominated flame retardants (e.g. polybrominated diphenyl ethers) may pose new 
threats to immune fitness in seals. Data on tissue concentrations of these compounds in seals in the North Sea area are scarce (Boon et al. 2002, Hall et al. 2003, Law et al. 2003), and information on the immunotoxicological impacts of these compounds on marine mammals is currently lacking. This prevents any firm conclusion on the role of these compounds in the resistance of seals to PDV.

\section{Long-term consequences and the risk of quasi-extinctions}

The re-occurrence of PDV in 2002 renewed interest in the possible long-term effects of repeated outbreaks on harbour seal populations (Harding et al. 2002). Risk assessment was used to investigate the sensitivity of projected populations under different future scenarios, taking account of stochastic population growth. The probability that populations declined to a lower threshold varied among regions, and it was determined that populations with low rates of increase and large annual variability in rates of increase (e.g. the Moray Firth and Wash populations) were most vulnerable to future mass mortality events (Harding et al. 2003). However, estimating extinction risk in rapidly growing populations was more difficult, as the exact value of population growth rate and its variance became crucial. Sampling error in survey data can exaggerate the variance in time series data (Lonergan \& Harwood 2003). Given long enough series, sampling error can be adjusted for by taking into account the auto correlation in the time series (McNamara \& Harding 2004). The outcome of risk assessments are also heavily dependant upon whether there was an upper ceiling to population size.

Irrespective of these issues, risk assessments are always best used as relative tools to compare one scenario to another. For example, with an upper boundary at 50000 individuals, the extinction risk (defined as the risk of a decline to $10 \%$ of initial population size over $100 \mathrm{yr})$ for the Kattegat-Skagerrak population increased from 0.09 in the absence of epidemics to 0.56 in the presence of epidemics (Harding et al. 2003). This estimate of extinction risk decreased when immunity was included, and increased when the upper boundary in population size was lowered. In a model without an upper boundary, the population was allowed to increase in an unlimited fashion between epidemics. The risk for declines to $10 \%$ of the population in this scenario was negligible in rapidly increasing seal populations without epidemics, but increased to about 0.05 with epidemics (Harding et al. 2003, Lonergan \& Harwood 2003). If $100 \%$ of the survivors after a PDV epidemic are assumed to be immune, then risk declined to less than 0.01 in exponentially growing, unlimited populations (Lonergan \& Harwood 2003). Obviously, lowering the assumed proportion of immune individuals among survivors' increased the estimated risk (Harding et al. 2003).

The data available on the dynamics and epidemiology of European harbour seals now provides unique opportunities for developing these frameworks to assess disease risks. In future, it will be important to vary the assumed frequency of epidemics from the current $14 \mathrm{yr}$ interval. It is also important to explore the ecological basis of different upper boundaries in population size. Metapopulation structure, where migration among colonies can buffer against local extinctions, should also be included. Although every model variation can give new interesting insights, they will also give a slightly new answer on exactly how large the risk is. Clearly PDV epidemics can have a significant impact on these populations, and the possibility of future outbreaks must be included in conservation and management plans.

\section{CONCLUSIONS}

PDV appears to have been circulating among several species of Arctic seals, which have provided a major reservoir for the virus. Migratory seal species such as harp seals and grey seals could act as vectors between Arctic and North Sea seal populations, and the 1988 and 2002 epidemics were likely to be the result of cross-species infections. However, the mechanisms for the propagation to harbour seals remain unclear. Harbour seals were infected first at Anholt in both 1988 and 2002. There are more than 100 harbour seal localities in Europe, and the chance 2 outbreaks being initiated at random from the same site is therefore less than 0.01. The emergence of the PDV epidemics at Anholt suggests that there may be specific conditions promoting cross-species infections at this site. Both the close contact between harbour seals and grey seals and the possible role of Anholt as a mixing zone between Atlantic and Baltic grey seals are 2 possible conditions that deserve further investigation. High levels of ecotoxins among harbour seals in the Kattegat could be a contributing factor.

The spread of the epidemics from Anholt to other North Sea regions cannot be entirely explained by known movement patterns of harbour seals, and grey seals may have also contributed to the dispersal of the PDV among harbour seal populations. The varying epidemic mortality among regions can be partly attributed to the season of infection, where populations affected in autumn suffered lower mortality. However, neither a genetic component nor the potential role of 
ecotoxins can be ruled out, especially since the same populations in western Norway and Kalmarsund in the Baltic escaped infection on both occasions. Despite the huge amount of research effort during both epidemics, such uncertainties highlight the difficulties of understanding host-pathogen dynamics in these large scale marine systems.

Acknowledgements. We thank the Swedish Environmental Protection Agency for support, and the Danish Ministry of Environment and the Governments of Lower Saxony and Schleswig-Holstein (Germany) for funds for the sampling program. The Dutch Ministry of Agriculture, Nature and Food Quality provided some funds for collection and storage of seal carcasses. The Dutch Ministry of Transport \& Public Works (Directorate N-Holland), the Produktschap Vis, and Alterra co-funded the processing of dead seals. Ecomare (The Netherlands) played a major role in collection of dead seals from the western Dutch Wadden Sea. Some of the 2002 UK data were collated under contract to the UK Department for Environment, Food and Rural Affairs. Becki Lawson assisted with UK data collection.

\section{LITERATURE CITED}

Acevedo-Whitehouse K, Gulland F, Greig D, Amos W (2003) Disease susceptibility in California sea lions. Nature 422: 35-35

Aguilar A, Raga JA (1993) The striped dolphin epizootic in the Mediterranean Sea. Ambio 22:524-528

Aguilar A, Borrell A, Reijnders PJH (2002) Geographical and temporal variation in levels of organochlorine contaminants in marine mammals. Mar Environ Res 53:425-452

Barrett T (1999) Morbillivirus infections, with special emphasis on morbilliviruses of carnivores. Vet Microbiol 69:3-13

Barrett T, Crowther J, Osterhaus ADME, Subbarao SM and 7 others (1992) Molecular and serological studies on the recent seal virus epizootics in Europe and Siberia. Sci Total Environ 115:117-132

Barrett T, Visser IKG, Mamaev L, Goatley L, Van Bressem MF, Osterhaus A (1993) Dolphin and porpoise morbilliviruses are genetically distinct from phocine distemper virus. Virology 193:1010-1012

Barrett T, Blixenkrone-Moller M, Di Guardo G, Domingo M, Duignan P, Hall A, Mamaev L, Osterhhaus ADME (1995) Morbilliviruses in aquatic mammals - report on round table discussion. Vet Microbiol 44:261-265

Bengtson J, Boveng P, Franzén U, Have P, Heide-Jørgensen MP, Härkönen T (1991) Antibodies to canine distemper virus in Antarctic seals. Mar Mamm Sci 7:85-87

Bergman A, Jarplid B, Svensson BM (1990) Pathological findings indicative of distemper in European seals. Vet Microbiol 23:331-341

Blixenkrone-Møller M, Svansson V, Have $\mathrm{P}$, Bøtner A, Nielsen J (1989) Infection studies in mink with sealderived morbillivirus. Arch Virol 106:165-170

Blixenkrone-Møller M, Bolt G, Gottschalk E, Kenner M (1994) Comparative analysis of the gene encoding the nucleocapsid protein of dolphin morbilliviruses. J Gen Virol 75: 2829-2834

Bohm J, Blixenkrone-Møller M, Lund E (1989) A serious outbreak of canine distemper among sled-dogs in northern Greenland. Arctic Med Res 48:195-203
Boon JP, Lewis WE, Tjoen-A-Choy MR, Allchin CR, Law RJ, de Boer J (2002) Levels of polybrominated diphenyl ether (PBDE) flame retardants in animals representing different trophic levels of the North Sea food web. Environ Sci Technol 36:4025-4032

Carter SD, Hughes DE, Bell SC, Baker JR (1990) Immune response in the common seals (Phoca vitulina) to canine distemper antigens during an outbreak of phocid distemper viral infection. J Zool Lond 222:391-398

Carter SD, Hughes DE, Taylor VJ, Bell SC (1992) Immune respons in common and grey seals during the seal epizootic. Sci Total Environ 115:83-91

Cornwell HJC, Anderson SS, Thompson PM, Mayer SJ, Ross HM, Pomeroy PP, Munro R (1992) The serological respons of the common seal (Phoca vitulina) and the grey seal (Halichoerus grypus) to phocine distemper virus as measured by a canine distemper virus neutralisation test. Sci Total Environ 115:99-116

Dietz R, Heide-Jørgensen MP, Härkönen T (1989a) Mass deaths of harbour seals (Phoca vitulina) in Europe. Ambio 18:258-264

Dietz R, Hansen CT, Have P, Heide-Jørgensen MP (1989b) Clue to seal epizootic? Nature 338:627

Dietz R, Heide-Jørgensen MP, Teilmann J, Valentin N, Härkönen T (1991) Age determination in European harbour seals Phoca vitulina. Sarsia 76:17-21

Dietz R, Teilmann J, Henriksen OD, Laidre K (2003) Movements of seals from Rødsand seal sanctuary monitored by satellite telemetry. Relative importance of the Nysted offshore wind farm area to the seals. Natl Environ Res Inst Tech Rep No. 429, Roskilde

Duignan PJ, Sadove S, Saliki JT, Geraci JR (1993) Phocine distemper in harbour seals (Phoca vitulina) from Long Island, New York. J Wildl Dis 29:465-469

Duignan PJ, Saliki JT, St Aubin DJ, House JA, Geraci JR (1994) Neutralizing antibodies to phocine distemper virus in atlantic walrus (Odobenus rosmarus rosmarus) from Arctic Canada. J Wildl Dis 30:90-94

Duignan PJ, Saliki JT, St Aubin DJ, Early G, Sadove S, House JA, Kovacs K, Geraci JR (1995a) Epizootiology of morbillivirus infection in North American harbour seals (Phoca vitulina) and grey seals (Halichoerus grypus). J Wildl Dis 31:491-501

Duignan PJ, House C, Geraci JR, Duffy N and 7 others (1995b) Morbillivirus infection in cetaceans of the Western Atlantic. Vet Microbiol 44:241-249

Duignan PJ, House C, Walsh MT, Campbell T and 6 others (1995c) Morbillivirus infection in manatees. Mar Mamm Sci 11:441-451

Duignan PJ, Nielsen O, House C, Kovacs KM and 6 others (1997a) Epizootiology of morbillivirus infection in harp, hooded, and ringed seals from the Canadian Arctic and western Atlantic. J Wildl Dis 33:7-19

Duignan PJ, Duffy N, Rima BK, Geraci JR (1997b) Comparative antibody response in harbour and grey seals naturally infected by a morbillivirus. Vet Immunol Immunopath 55: 341-349

Galvani AP, Slatkin M (2004) Intense selection in an agestructured population. Proc R Soc Lond B 271:171-176

Goodman SJ (1995) Molecular population genetics of the European harbour seal (Phoca vitulina) with reference to the 1988 phocine distemper virus epizootic. $\mathrm{PhD}$ thesis, University of Cambridge

Goodman SJ (1998) Patterns of extensive genetic differentiation and variation among European harbour seals (Phoca vitulina vitulina) revealed using microsatellite DNA polymorphisms. Mol Biol Evol 15:104-118 
Grachev MA, Kumarev VP, Mamaev LV, Zorin VL and 10 others (1989) Distemper virus in Baikal seals. Nature 338:209

Hall AJ, Duck CD, Law RJ, Allchin CR, Wilson S, Eybator T (1999) Organochlorine contaminants in Caspian and harbour seal blubber. Environ Pollut 106:203-212

Hall AJ, Law RJ, Wells DE, Harwood J and 5 others (1992a) Organochlorine levels in common seals (Phoca vitulina) which were victims and survivors of the 1988 phocine -distemper epizootic. Sci Total Environ 115:145-162

Hall AJ, Pomeroy PP, Harwood J (1992b) The descriptive epizootiology of phocine distemper in the UK during 1988/89. Sci Total Environ 115:31-44

Hall A, Kalantzi O, Thomas G (2003) Polybrominated diphenyl ethers (PBDEs) in grey seal pups during their first year of life-are they thyroid hormone endocrine disrupters? Environ Pollut 126:29-37

Hammond JA, Pomeroy PP, Hall AJ, Smith VJ (2005) Identification and real-time PCR quantification of phocine distemper virus from two colonies of Scottish grey seals in 2002. J Gen Virol 86:2563-2567

Harder T, Willhaus T, Frey HR, Liess B (1990) Morbillivirus infections of seals during the 1988 epidemic in the Bay of Helgoland. Transmission studies of cell culture-propagated phocine distremper virus in harbor seals serological results. J Vet Med B 37:641-650

Harding KC, Härkönen T, Caswell H (2002) The 2002 European seal plague: epidemiology and population consequences. Ecol Lett 5:727-732

Harding KC, Härkönen T, Pineda J (2003) Estimating quasiextinction risk of European harbour seals: a reply to Lonergan and Harwood. Ecol Lett 6:894-897

Härkönen T, Harding KC (2001) Spatial structure of harbour seal populations and the implications thereof. Can J Zool 79:2115-2127

Härkönen T, Heide-Jørgensen MP (1990) Comparative life histories of East Atlantic and other harbour seal populations. Ophelia 32:211-235

Härkönen T, Harding KC, Lunneryd SG (1999) Age and sex specific behaviour in harbour seals leads to biased estimates of vital population parameters. J Appl Ecol 36: $824-840$

Härkönen T, Harding KC, Heide-Jørgensen MP (2002) Rates of increase in age structured populations: a lesson from the European harbour seals. Can J Zool 80:1498-1510

Härkönen T, Brasseur S, Teilmann J, Vincent C, Dietz R, Abt K, Reijnders P (2006) Status of grey seals along mainland Europe from the Southwestern Baltic to France. NAMMCO Sci Publ (in press)

Harvell CD, Kim K, Burkholder JM, Colwell RR and 9 others (1999) Emerging marine diseases-climate links and anthropogenic factors. Science 285:1505-1510

Harwood J, Hall A (1990) Mass mortality in marine mammals-its implications for population-dynamics and genetics. Trends Ecol Evol 5:254-257

Harwood J, Carter SD, Hughes DE, Bell SC, Baker JR, Cornwell HJC (1989) Seal disease predictions. Nature 339:670

Haug T, Kroyer AB, Nilssen KT, Ugland KI, Aspholm PE (1991) Harp seal (Phoca groenlandica) invasions in Norwegian coastal waters-age composition and feedinghabits. ICES J Mar Sci 48:363-371

Heide-Jørgensen MP, Härkönen T (1992) Epizootiology of seal disease. J Appl Ecol 29:99-107

Heide-Jørgensen MP, Härkönen T, Dietz R, Thompson P (1992) Retrospective of the 1988 European seal epizootic Dis Aquat Org 13:37-62

Henderson G, Trudgett A, Lyons C, Ronald K (1992) Demonstration of antibodies in archival sera from Canadian seals reactive with the European isolate of phocine distemper virus. Sci Total Environ 115:93-98

ICES (1989) Report of the joint meeting of the working group of Baltic seals and the study group on the effects of contaminants on marine mammals. ICES Counc Meet Pap 1989/N:9

Jensen T, van de Bildt M, Dietz HH, Andersen TH, Hammer AS, Kuiken T, Osterhaus A (2002) Another phocine distemper outbreak in Europe. Science 297:209

Jepson PD, Bennett PM, Deaville R, Allchin CR, Baker JR, Law RJ (2005) Relationships between polychlorinated biphenyls and health status in harbor porpoises (Phocoena phocoena) stranded in the United Kingdom. Environ Toxicol Chem 24:238-248

Kennedy S (1990) A review of the 1988 European seal morbillivirus epizootic. Vet Rec 127:563-567

Kennedy S, Kuiken T, Jepson PD, Deaville R and 9 others (2000) Mass die off of Caspian seals caused by canine distemper virus. Emerg Infect Dis 6:637-639

Klingeborn B (1990) Rapport från projektet valpsjukeliknande virus från säl före och efter sälepizootin orsakad av ett sådant virus 1988. Swedish Environmental Protection Board, Stockholm

Kuiken T, Simpson VR, Allchin CR, Bennett PM and 8 others (1994) Mass mortality of common dolphins (Delphinus delphis) in south-west England due to incidental capture in fishing gear. Vet Rec 134:81-89

Law RJ, Mehran A, Allchin CR, Boon JP, Lebeuf M, Lepom P, Stern GA (2003) Levels and trends of polybrominated diphenylethers and other brominated flame retardants in wildlife. Environ Int 29:757-770

Lawson B, Jepson PD (eds) (2004) UK phocine distemper virus epizootic: investigation report 2002/2003. Department for Environment, Food and Rural Affairs, London

Lipscomb TP, Schulman FY, Moffett D, Kennedy S (1994) Morbilliviral-disease in Atlantic bottle-nosed dolphins (Tursiops truncatus) from the 1987-1988 epizootic. J Wildl Dis 30:567-571

Lonergan M, Harwood J (2003) The potential effects of repeated outbreaks of phocine distemper among harbour seals: a response to Harding et al. (2002). Ecol Lett 6: 889-893

Mamaev LV, Denikina NN, Belikov SI, Volchkov VE and 7 others (1995) Characterisation of morbilliviruses isolated from Lake Baikal seals (Phoca sibirica). Vet Microbiol 44: 251-259

Markussen NH, Have P (1992) Phocine distemper virus infection in harp seals (Phoca groenlandica). Mar Mamm Sci 8: $19-26$

McCollugh SJ, McNeilly F, Allan GM, Kennedy S, Smyth JA, Cosby SL, McQuaid S, Rima BK (1991) Isolation and characterisation of a porpoise morbillivirus. Arch Virol 118: $247-252$

McNamara JM, Harding KC (2004) Measurement error and estimates of population extinction risk. Ecol Lett 7:16-20

Müller G, Wohlsein P, Beineke A, Haas L and 7 others (2004) Phocine distemper in german seals, 2002. Emerg Inf Dis 10:723-725

Nielsen O, Stewart REA, Measures L, Duignan P, House C (2000) A morbillivirus antibody survey of Atlantic walrus, narwhal and beluga in Canada. J Wildl Dis 36:508-517

O'Shea TJ, Rathbun GB, Bonde RK, Buergelt CD, Odell DK (1991) An epizootic of Florida manatees associated with a dinoflagellate bloom. Mar Mamm Sci 7:165-179

Osterhaus ADME, Vedder EJ (1988) Identification of virus causing recent seal deaths. Nature 335:20

Osterhaus ADME, Groen J, Vries P, UytdeHaag FGMC, 
Klingeborn B, Zarnke R (1988) Canine distemper virus in seals. Nature 335:403-404

Osterhaus ADME, Groen J, UytdeHaag FGMC, Visser IKG, Vedder EJ, Crowther J, Bostock CJ (1989) Morbillivirus infections in European seals before 1988. Vet Rec 16:326

Paterson S, Wilson K, Pemberton JM (1998) Major histocompatibility complex variation associated with juvenile survival and parasite resistance in a large unmanaged ungulate population (Ovis aries L). Proc Natl Acad Sci 95: $3714-3719$

Reijnders PJH, Aguilar A (2002) Pollution and marine mammals. In: Perrin WF, Wursig B, Thewissen JGM (eds) Encyclopedia of marine mammals. Academic Press, San Diego, CA, p 948-956

Reijnders PJH, Brasseur SMJM (2003) Vreemde snuiten aan de Nederlandse kust. Zoogdier 14:5-10

Reijnders PJH, Simmonds MP (2003) Global temporal trends of organochlorines and heavy metals in pinnipeds. In: Vos JG, Bossart GD, Fournier M, O'Shea T (eds) Toxicology of marine mammals. Taylor \& Francis, London, p 491-506

Reijnders PJH, van Dijk J, Kuiper D (1995) Recolonization of the Dutch Wadden Sea by the grey seal Halichoerus grypus. Biol Cons 71:231-235

Reijnders PJH, Ries EH, Tougaard S, Nørgaard N, Heidemann G, Schwarz J, Vareschi E, Traut IM (1997) Population development of harbour seals Phoca vitulina in the Wadden Sea after the 1988 virusepizootic. J Sea Res 38:161-168

Ries EH (1999) Population biology and activity patterns of harbour seals in the Wadden Sea. PhD thesis, Groningen University

Rima BK, Curran MD, Kennedy S (1992) Phocine distemper virus, the agent responsible for the 1988 mass mortality of seals. Sci Total Environ 115:45-55

Ross PS (2002) The role of immunotoxic environmental contaminants in facilitating the emergence of infectious diseases in marine mammals. Hum Ecol Risk Assess 8: $277-292$

Editorial responsibility: Jay Levine, Raleigh, North Carolina, USA
Samson M, Libert F, Doranz BJ, Rucker J and 18 others (1996) Resistance to HIV-1 infection in caucasian individuals bearing mutant alleles of the CCR-5 chemokine receptor gene. Nature 382:722-725

Scholin CA, Gulland F, Doucette GJ, Benson S and 22 others (2000) Mortality of sea lions along the central California coast linked to a toxic diatom bloom. Nature 403:80-84

Søndergaard NO, Joensen AH, Hansen EB (1976) Sælernes forekomst og sæljagten i Danmark (The occurrence of seals and the seal hunt in Denmark). Danske Viltundersøgelser hefte 16, Viltbiologisk Station

Stanley HF, Casey S, Carnahan JM, Goodman S, Harwood J, Wayne RK (1996) Worldwide patterns of mitochondrial DNA differentiation in the harbour seal. Mol Biol Evol 13: 368-382

Swinton J, Harwood J, Grenfell BT, Gilligan CA (1998) Persistence thresholds for phocine distemper virus infection in harbour seal (Phoca vitulina) metapopulations. J Anim Ecol 67:54-68

Thompson P, Miller D (1992) Phocine distemper out-break in the Moray Firth common seal population. Sci Total Environ 115:54-63

Thompson PM, Thompson H, Hall A (2002) Prevalence of morbillivirus antibodies in Scottish seals. Vet Rec 151: $609-610$

Thompsen D, Lonergan ME, Duck C (2005) Population dynamics of harbour seals (Phoca vitulina) in England: growth and catastrophic declines. J Appl Ecol 42:638-648

Trillmich F, Dellinger T (1991) The effects of El Niño on Galapagos pinnipeds. Ecol Stud 88:66-74

Van Bressem MF, Van Waerebeek K, Jepson PD, Raga JA and 13 others (2001) An insight into the epidemiology of dolphin morbillivirus worldwide. Vet Microbiol 81:287-304

Visser IKG, Kumarev V, Orvell C, Vries P and 7 others (1990) Comparison of two morbilliviruses isolated from seals during outbreaks of distemper in north west Europe and Siberia. Arch Virol 111:149-164

Submitted: July 29, 2004; Accepted: October 11, 2005

Proofs received from author(s): January 16, 2006 